\title{
L'anniversaire des "Annales". The Year 2014 as the Time of French Anniversaries of Marc Bloch, Philipp Aries and Jacques le Goff
}

\begin{abstract}
Article presents achievements of three French historians: Marc Bloch (1886-1944), Philipp Ariès (1914-1984) and Jacques le Goff (1924-2014). They were founders and leaders of Annales school in historiography. Marc Bloch was fascinated by the history of the Middle Ages, especially the history of the French countryside and feudalism, as well as the social history of medieval France. Philippe Ariès was also passionate about the history of the Middle Ages, but unlike Bloch, he was more interested in everyday matters such as death and childhood. Thanks to his work on childhood, he made a breakthrough in historiography dealing with such a delicate and elusive topic, while making very radical judgments about the issue. Jacques le Goff was known in the Annalist community as the creator of nouvelle histoire, i.e. historical anthropology and the history of mentality. Thanks to historians like J. Le Goff, history seemed more interesting and "fresh", even, and above all, the history of the Middle Ages.
\end{abstract}

Keywords: Marc Bloch, Philipp Ariès, Jacques le Goff, Annales

For researchers of history and advocates of the new social vision of history, especially of the French provenance, the year 2014 is or should be atypical. First of all, due to the anniversAriès falling at that time of the birth and death of three French historians: Marc Bloch (1886-1944), Philipp Ariès (1914-1984) and Jacques le Goff (1924-2014). Each of them represents one generation of researchers gathered around the journal "Annales. Économies - Sociétés - Civilization", published since 1929, which thanks to its authors and their publications, led to a small/large revolution in the teachings about the past. This multiplicity of anniversAriès is, therefore, a good opportunity to recall these historians and their achievements. The more so, that the younger generation of students, and even some researchers, tend to forget about them.

The first one, Marc Bloch, is considered the "father - founder of Annales". Witold Kula wrote that next to Lucien Febvre he was a pioneer who did not accept anything which 
he found [in historical sciences] passively, he was the one who led the fight for new issues being raised in history, he proposed new categories of sources and new methods of working with them ${ }^{1}$. In addition, this professor of universities in Strasbourg, Clermont-Ferrand, Montpellier and the famous Sorbonne, also known as "Narbonne", was an activist of the French resistance movement, for which he was finally murdered by the Gestapo.

Marc Leopold Beniamin Bloch was born in Lyon on July 6, 1886 in the Jewish family of Gustav Bloch - professor of ancient history. He spent his childhood and teenage years in Paris, where he also studied history and geography at École Normale Supérieure. He completed his supplementary studies in Leipzig and Berlin. He also worked as a high school teacher, which is still a common practice in France today. He fought on the fronts of the First World War, finishing with the rank of captain and the Knight of the Legion of Honour. As a university lecturer and researcher, he was fascinated by the history of the Middle Ages, especially the history of the French countryside and feudalism, as well as the social history of medieval France. He wrote many works, to the extent that it was difficult to compile a full bibliography of all his works. Some of his books remained unfinished. He was an active scientist during World War II, but he also got involved in the work of the French resistance movement. He was arrested, tortured and murdered by the Gestapo on June 16, 1944, a few weeks before the liberation. His death has its consequences to this day, because after the fall of the Berlin Wall, the governments of France and Germany decided to open a French-German research centre for social sciences that would be open to Europe. It was opened on October 9, 1992, and less than two years later it was named the Marc Bloch Centre to commemorate this eminent historian. The first director of the institute was the historian Étienne François (1992-1999). His successor was the philosopher Catherine Colliot-Thélène (2000-2005), followed by a political scientist Pascale Laborier (2005-2010). Currently, the director is the historian Patrice Veit ${ }^{2}$.

The most important works of Marc Bloch include:

Les rois thaumaturges, 1924. Królowie cudotwórcy. Studium na temat nadprzyrodzonego charakteru przypisywanego władzy królewskiej zwłaszcza we Francji $i$ w Anglii, préface by Jacques Le Goff, trans. Jan Maria Kłoczowski, Warsaw: „Volumen” „Bellona” 1998.

Les caracters originaux de l'histoire rurale française, 1931.

La société féodale, 1939-1940. Społeczeństwo feudalne, préface by Andrzej Feliks Grabski, transl. Eligia Bąkowska, Warsaw: Państwowy Instytut Wydawniczy 1981 (2nd edition Warsaw: Państwowy Instytut Wydawniczy 2002.

Apologie pour l'Histoire, 1940. Pochwała historii czyli O zawodzie historyka, reviewed and préface by Witold Kula, transl. Wanda Jedlicka, Warsaw: Państwowe Wydawnictwo Naukowe 1960 , 2nd edition Warsaw: Państwowe Wydawnictwo Naukowe 1962, 3rd edition, transl., supplemented, edited, reviewed and prefaced by Hubert Łaszkiewicz, Kęty: Wydawnictwo Marek Derewiecki 2009.

\footnotetext{
${ }^{1}$ KULA, W., Préface, [in:] BLOCH, M., Pochwała historii czyli o zawodzie historyka, Wydawnictwo Marek Derewiecki, Kęty 2009, p. 15.

${ }^{2}$ www.cmb.hu-berlin.de/en/ (access date: 4 January 2015).
} 
L'étrange défaite, 1957. Dziwna klęska, transl. Katarzyna Marczewska, Warsaw: Oficyna Naukowa 2008.

Souvenirs de guerre 1914-1915, 1969.

Philippe Ariès was born on July 21, 1914 in Blois. He was a graduate of Sorbonne, where he studied history and geography. He was also passionate about the history of the Middle Ages, but unlike Bloch, he was more interested in everyday matters such as death and childhood. Thanks to his work on childhood, he made a breakthrough in historiography dealing with such a delicate and elusive topic, while making very radical judgments about the issue. He was more valued in other countries than in his native France. He died in Paris on February 8, $1984^{3}$.

His most important works include:

Le Temps de l'histoire, 1954. Czas historii, Gdańsk-Warszawa 1996, Wydawnictwo Marabut co-published with Oficyna Wydawnicza Volumen.

L'Enfant et la vie familiale sous l'Ancien Régime, 1960. Historia dzieciństwa. Dziecko i rodzina $w$ dawnych czasach, Gdańsk 1995, Wydawnictwo Marabut.

Essais sur l'histoire de la mort en Occident: du Moyen Âge à nos jours, 1975. Rozważania o historii śmierci, Warsaw 2007, Oficyna Naukowa.

L’Homme devant la mort, 1977. Człowiek i śmierć, Warsaw 1989, 1992, Państwowy Instytut Wydawniczy.

Histoire de la vie privée, 1985-1986-1987. Historia życia prywatnego, (ed. vol. 1-5 with Georges Duby) Wrocław 1999, 2006, Zakład Narodowy im. Ossolińskich Antropologia śmierci. Myśl francuska, selected and translated by Stanisław Cichowicz, Jakub M. Godzimirski, preface by Stanisław Cichowicz, anthology of texts by Philippe Ariès and others, Warsaw 1993, Wydawnictwo Naukowe PWN.

Jacques le Goff was born on January 1, 1924 in Toulon. Like Bloch, he studied at École Normale Supérieure, then at Oxford and Rome. During World War II, he was a member of the resistance movement, like Bloch. He is known /was known in the Annalist community as the creator of nouvelle histoire, i.e. historical anthropology and the history of mentality. Thanks to historians like J. Le Goff, history seemed more interesting and "fresh", even, and above all, the history of the Middle Ages. Promoting history as a discipline was also extremely important for Le Goff - for this purpose, among other things, he was involved in shaping history curricula and didactics itself. He collaborated with Fernand Braudel, and in 1972 he took over the position of the President of the Paris École des hautes études en sciences sociales (Higher School of Social Science, earlier the sixth section of the École pratique des hautes études). Three years earlier he became the editor of "Annales. Histoire, Sciences sociales"- the most important historical magazine of the 20th century 4 .

${ }^{3}$ GROS, G., Philippe Ariès, un traditionaliste non-conformiste. De l'Action française à l'Ecole des hautes études en sciences sociales, Presses Universitaires du Septentrion, Villeneuve d'Ascq, 2008. Also see: http:// philippe-Ariès.histoweb.net/.

${ }^{4}$ http://histmag.org/ (access date: 5 January 2015). 
He had numerous contacts with Poland - firstly thanks to his wife Anna (Hanna) Dunin-Wąsowicz, and then through friendly contacts with Polish eminent historians Witold Kula, Bronisław Geremek, Henryk Samsonowicz and Karol Modzelewski. He was a foreign member of the Polish Academy of Sciences and an honorary doctor of the University of Warsaw and the Jagiellonian University. He knew Polish, his teacher in this field was Professor Barbara Skarga ${ }^{5}$.

He is probably the best-known and most popular annalist in Poland, considering the number of his works translated into Polish and their numerous reissues:

Les intellectuels au Moyen Âge, 1957. Inteligencja $w$ wiekach średnich, 1st edition: Czytelnik, Warsaw 1966, 2nd edition: Volumen and Bellona, Warsaw 1997.

Civilisation de l'Occident médiéval, 1964. Kultura średniowiecznej Europy,1st edition:

Warsaw 1970, PWN, 2nd edition: Warsaw 1994, Volumen and Klon, 3rd edition: Gdańsk-Warszawa 2002, Volumen i Marabut.

L’Homme médiéval, 1994. Człowiek średniowiecza (ed.) 1st edition: Volumen and Marabut, Gdańsk-Warszawa 1996, Man and Society series, 2nd edition: Świat Książki, Warsaw 2000

La bourse et la vie, 1986. Sakiewka i życie. Gospodarka i religia w średniowieczu, Marabut, Gdańsk 1995.

La naissance du purgatoire, 1981. Narodziny czyśćca, PIW, Warsaw 1997.

L’imaginaire médiéval, 1985. Świat średniowiecznej wyobraźni, Volumen and Bellona, Warsaw 1997.

Saint François d'Assise, 1999. Święty Franciszek z Asyżu, Czytelnik, Warsaw 2001.

Saint Louis, 1995. Święty Ludwik, Volumen, Warsaw 2001.

Le XIIIe siècle. L'apogée de la chrétienté, 1992. Apogeum Chrześcijaństwa. Około $1180-$ ok. 1330, Czytelnik, Warsaw 2003.

L’Europe racontée aux jeunes, 1996. Historia Europy dla dzieci, Świat Książki, Warsaw 2004

Plus belle histoire de l'amour, 2003. Najpiękniejsza historia miłości (with Dominique Simonnet, Jean Courtin, Paul Veyne, Jacques Solé, Mona Ozouf, Alain Corbin, Ann-Marie Sohn, Pascal Bruckner, Alice Ferney) Wydawnictwo Cyklady, Warsaw 2004.

À la recherche du Moyen Âge, 2003. W poszukiwaniu średniowiecza (with Jean-Maurice de Montremy), Czytelnik, Warsaw 2005.

Histoire du corps au Moyen âge, 2003. Historia ciała $w$ średniowieczu (with Nicolas Truong) Czytelnik, Warsaw 2006.

Long moyen âge, 2004. Dlugie średniowiecze, Wydawnictwa Uniwersytetu Warszawskiego, Warsaw 2007.

Histoire et memoire, 1988. Historia i pamięć, Wydawnictwa UW, Warsaw 2007.

Moyen Âge expliqué aux enfants. O średniowieczu, Oficyna Naukowa, Warsaw 2007.

Le Dieu du Moyen Âge, 2003. Bóg średniowiecza. Interviews with Jean-Luc Pouthier, Wydawnictwa Uniwersytetu Warszawskiego, Warsaw 2008.

${ }^{5}$ GŁAŻEWSKI, J., [Francja/Polska] Jakub od św. Ludwika - Jacques Le Goff (1924-2014), [in:] http:// kulturaliberalna.pl/ (access date: 5 January 2015). 
Le Moyen Âge et l'Argent, 2010. Średniowiecze i pieniadze. Esej z antropologii historycznej, Czytelnik, Warsaw 2011.

Héros et merveilles du Moyen Âge, 2005. Niezwykli bohaterowie i cudowne budowle średniowiecza, Oficyna Naukowa, Warsaw 2011.

There were a lot of differences between these three representatives of the Annales school, also in their biographies, which is natural, considering the times in which they lived. But more things connected them. This was, above all, a love for learning, respect for the past and responsibility and humbleness towards posterity. What do we owe to the "annalists"?

One of the researchers summed up the output of the "Annales" school in the following manner:

"The activity of the so-called Annales school, its contributors and allies, promoted new historical science. As a result, after years of struggle with "old" history in the period of 1950-1970, new history gained its place in historical science. What is more, it achieved, at least in France, an intellectually, institutionally and propaganda-dominant position, not only in historiography, but also in the humanities" ${ }^{\circ}$.

Historians such as Bloch, Ariès and Le Goff had the courage to reject the superior values prevailing in traditional historiography, such as the individual, politics and chronology. They also reinterpreted traditional historiographical metaphors, including the idea of genesis, progress, linear time, cause-and-effect thinking? ${ }^{7}$. We owe the Annalists a different vision of man and the world in history, but also a permanent union of history with other disciplines such as: economics, sociology, psychology, geography, demography ${ }^{8}$. Such a rich and diverse viewpoint on the past resulted in the fact that it is now more complete, more understandable and closer to people. It is also closer to researchers, because the scope of research on nouvelle histoire is so broad that it allows for different research approaches and theoretical inspirations ${ }^{9}$. Hence, research on something as elusive as childhood, death, mentality, religiosity, purgatory, imagination or love.

Bloch himself wrote in his work "L'Étrange défaite" that:

„Our school programs, dealing almost exclusively with the most superficial phenomena of peoples' lives ... shy away from any analysis of social life phenomena"10.

${ }^{6}$ COUTAU-BEGARIE, H., Le phénomène Nouvelle Histoire, Paris 1983. Quoted after: W. WRZOSEK, Metafory historiograficzne w pogoni za ułuda prawdy, [in:] DOMAŃSKA, E., TOPOLSKI, J., WRZOSEK, W., Między modernizmem a postmodernizmem. Historiografia wobec zmian w filozofii historii, Wydawnictwo Naukowe UAM, Poznań 1994, p. 6.

${ }^{7}$ GRABSKI, A.F., Dzieje historiografii, Wydawnictwo Poznańskie, Poznań 2003; TOPOLSKI, J., Od Achillesa do Beatrice de Planissolles. Zarys historii historiografii, Oficyna Wydawnicza Rytm, Warsaw 1998.

${ }^{8}$ Ibidem, p. 6-9. Also see: WRZOSEK, W., Historia - Kultura-Metafora. Powstanie nieklasycznej historiografii, Wydawnictwo Leopoldinum, Wrocław 1995, p. 124-142.

${ }^{9}$ WRZOSEK, W., Metafory historiograficzne, p. 11.

${ }^{10}$ BLOCH, M., L’Étrange défait, p. 173. Quoted after: W. KULA, Préface, op. cit., p. 19. 
Great history based on politics and events (evenementielle) that so far dominated science was to be replaced by social history, where problems would replace facts, processes would replace events, ordinary human masses instead of "big units" door to practicing science for followers of, for example, the history of everyday life or the history of women ${ }^{12}$. So that history would finally become the history of people and history for people ${ }^{13}$. Ordinary people.

Jacques le Goff once wrote that the heroes of his books will never die. These words also refer to the researchers and authors of wonderful books which have introduced the non-existent world ${ }^{14}$.

\section{Bibliography}

bibliobs.nouvelobs.com (access date:4 january 2015).

COUTAU-BEGARIE, H., Le phénomène Nouvelle Histoire, Paris 1983.

GŁAŻEWSKI, J., [Francja/Polska] Jakub od św. Ludwika - Jacques Le Goff (1924 - 2014), [in :] http://kulturaliberalna.pl/ (access date:4 january 2015).

GRABSKI, A.F., Dzieje historiografii, Poznań 2003.

GROS, G., Philippe Ariés, un traditionaliste non - conformiste. De l'Action francaise à l'école des hautes études en sciences sociales, Villeneuve d'Ascq, 2008.

Historia ludzi. Historia dla ludzi. Krytyczny wymiar edukacji historycznej, ed. I., CHMURA RUTKOWSKA, E., GŁOWACKA -SOBIECH, and I., SKÓRZYŃSKA, Kraków 2013.

http://philippe-Ariès.histoweb.net/. (access date:4 january 2015).

KULA, W. Préface, [in:] BLOCH, M., Pochwała historii, czyli o zawodzie historyka, Kety 2009.

PERROT, M., Mon histoire des femmes, 2006.

TOPOLSKI, J., Od Achillesa do Beatrice de Planissolles. Zarys historii historiografii, Warsaw 1998.

WRZOSEK, W., Historia - Kultura - Metafora. Powstanie nieklasycznej historiografii, Wrocław 1995.

WRZOSEK, W., Metafory historiograficzne w pogoni za ułuda prawdy, [in:] DOMAŃSKA, E., TOPOLSKI, J., WRZOSEK, W., Miedzy modernizmem a postmodernizmem. Historiografia wobec zmian w filozofii historii, Poznań 1994.

www.cmb.hu-berlin.de/en/ (access date:4 january 2015).

Originally published in "Biuletyn Historii Wychowania", 2014, vol. 32, pp. 137-142

\footnotetext{
${ }^{11}$ KULA, W., Préface, op. cit., p. 19. 2006.

${ }^{12}$ See e.g.: the work and activity of Michelle Perrot, Mon histoire des femmes, Seuil France Culture,

${ }^{13}$ Historia ludzi. Historia dla ludzi. Krytyczny wymiar edukacji historycznej, ed. I., CHMURA-RUTKOWSKA, E., GŁOWACKA-SOBIECH, and I., SKÓRZYŃSKA, Oficyna Wydawnicza Impuls, Kraków 2013.
}

${ }^{14}$ bibliobs.nouvelobs.com (access date: 5 January 2015). 